УДК 633.65

(C) 2013

Шевніков М. Я., доктор сільськогосподарських наук, професор, Кулібаба М. Ю., аспірант *

Полтавська державна аграрна академія

\title{
УРОЖАЙНІСТЬ ТА ЯКІСТЬ НАСІННЯ СОЇ ЗАЛЕЖНО ВІД СТРОКІВ СІВБИ І ВИКОРИСТАННЯ БІОПРЕПАРАТІВ
}

Рецензент - доктор сільськогосподарських наук, професор П. В. Писаренко

Урожайність та якість урожаю сої залежала як від строків сівби, так і від передпосівної обробки насіння. Передпосівна обробка «Ризогуміном» позитивно вплинула на продуктивність азотфіксаиіі $i$, як наслідок, на врожайність культури. На ділянках, де рослини у ході сівби були оброблені біопрепаратом за всіх трьох строків сівби, структурні показники врожаю та маса 1000 насінин були вищиими. Маса 1000 насінин у разі використання

біопрепарату відрізнялася в середньому

на 6,4-8,6 грамів. Різні строки сівби помітно вплинули на тривалість періоду вететації рослин. Найдовшим він був за ранньої сівби і в подальшому скорочувався на 6-9 днів.

Ключові слова: строки сівби, азотфіксуючі мікроорганізми, азотфіксаиія, Rhizobium, бioпрепарати, інокулячія, «Ризогумін».

Постановка проблеми. Одна 3 найбільш важливих проблем сільського господарства сучасності - недостатне виробництво рослинного білку. Суттєве значення у розв'язанні цієї проблеми має соя- як харчова, кормова й технічна культура. Саме тому підвищення продуктивності посівів даної культури в наш час $\epsilon$ одним із актуальних питань.

Оскільки продуктивність сої значно знижується через шкоду, що їі завдають бур'яни, хвороби та шкідники, а також у значній мірі залежить від кількості опадів за рік, основним напрямом його вирішення в зоні недостатнього зволоження Лівобережного Лісостепу $є$ інтенсифікація технології вирощування.

Аналіз основних досліджень і публікацій, у яких започатковано розв'язання проблеми. Основними прийомами формування продуктивності є вибір оптимальних строків сівби [2], використання добрив, пестицидів та біопрепаратів. В умовах переходу на систему альтернативного землеробства [5] особливого значення набуває використання рослинами біологічного азоту, що нешкідливо для інших живих організмів [3]. Саме тому соя як азотфіксуюча рослина відіграє ще одну важливу роль. Азотфіксація проходить в особливих утвореннях - бульбочках, що формуються за рахунок симбіозу рослини 3 азотфіксуючими мікроорганізмами. Бульбочки представляють собою невеликі потовщення на коренях, заселені колоніями бактерій роду Rhizobium [8]. У процесі росту рослини до коренів стягуються переважно ті азотфіксатори, які у процесі еволюції пристосувалися до співжиття 3 відповідними видами рослин. Вони нагромаджуються в молодих тканинах головного та бічних коренів, де інтенсивно розмножуються поділом, утворюючи так звані інфекційні нитки. Під впливом життєдіяльності бактерій клітини кореня розростаються у кулясті бульбочки [6]. Обробка насіння біопрепаратами (таким як «Ризогумін») покликана збільшити ефективність цього симбіозу, поскільки виведені штами бульбочкових бактерій володіють кращими продуктивними властивостями. Крім того, в грунтах півдня, центру та сходу України існують аборигенні популяції бульбочкових бактерій гоpoxy, бобів, вики, чини, сочевиці (Rhizobium leguminosarum bv. vicea), конюшини (Rhizobium trifolii), люцерни, буркуну, тригонели (Sinorhizobium meliloti), лядвенцю (Mesorhizobium loti), здатні забезпечити інокуляцію відповідних бобових рослин. Чисельність цих бактерій у шарі грунту 0-10 см становить $10^{3}$ бульбочкоутворювальних одиниць (БУО) в 1 г грунту. Аборигенні бульбочкові бактерії coї (Bradyrhizobium japonicum), квасолі (Rhizobium phaseoli), нуту (Mesorhizobium ciceri), люпину (Rhizobium lupini), козлятнику східного (Rhizobium galegae) виявлені лише на місцях, де раніше вже росли ці культури $[1,7]$.

" Науковий керівник - доктор сільськогосподарських наук, професор М. Я. Шевніков 
Мета і завдання дослідження. Метою дослідження було розробити ресурсозберігаючу технологію вирощування сої, що забезпечить підвищення врожайності, покращання якості зерна та активізацію азотфіксуючої здатності.

Завдання досліджень - вивчити вплив строків сівби та передпосівної обробки насіння біопрепаратом «Ризогумін» i на основі цього розробити ресурсозберігаючу технологію вирощування сої.

Матеріали і методи досліджень. У 2012 році дослід проводився на дослідному полі Полтавського інституту АПВ ім. М. І. Вавилова. Агротехніка вирощування сої - типова для зони Лівобережного Лісостепу, крім елементів технології, що вивчалися. Площа дослідної ділянки - $60 \mathrm{~m}^{2}$, облікової - $30 \mathrm{~m}^{2}$, повторність варіантів - триразова; варіанти розміщені систематично. Об'єктом дослідження був сорт Білосніжка; сівбу проводили необробленим насінням і насінням, інокульованим препаратом «Ризогумін», у три строки (27 квітня, 4 травня, 13 травня). Обробка проводилася в день сівби. Попередник - пшениця озима.

Результати досліджень. У ході досліду проводилися спостереження за розвитком рослин (табл. 1). За ранньої сівби сходи з'явилися на 8-й день, за оптимальної і пізньої - через 9 та 8 днів відповідно; період проростання збільшився до 10 днів. За тривалістю фенологічні фази найдовше проходили за першого строку сівби, за 2-го і 3-го строків їх тривалість скоротилася на 3-6 днів.

У цілому найдовший вегетаційний період (100 днів) був за раннього строку сівби, а в подальшому (в умовах нестачі продуктивної вологи) він скорочувався на 6-9 днів.

Через різницю в часі за настання фенологічних фаз i надзвичайно екстремальні погодні умови року, забезпечення вологою рослин сої за різних строків сівби також було неоднакове. За раннього строку сівби достатня кількість опадів після сходів позитивно вплинула на інтенсивний ріст і розвиток, але в подальшому фази формування і наливу бобів проходили за умов недостатнього зволоження, що значно уповільнило процеси генеративного розвитку. За другого строку сівби утворення та наливання бобів також проходило з мінімальним зволоженням і за підвищених температур, а зволоження було достатне лише в період сходів та цвітіння. За пізньої сівби недостатня кількість продуктивної вологи спостерігалася вже в період «цвітіння - утворення бобів», що негативно позначилося на їх кількості.

Дослід передбачав визначення впливу досліджуваних факторів на ріст і розвиток рослин сої у фазу наливу бобів у середньому ярусі. Підрахунки проводилися 2, 12 та 23 липня і включали вимір висоти рослин, підрахунок кількості листків на рослинах і кількості бульбочок $з$ однієї рослини (див. рис.). Як видно з даних діаграм, висота рослин була більшою на варіантах оптимального строку сівби, інокульованих у ході сівби «Ризогуміном» станом на 2 липня - 59,2 см, у той час як висота рослин раннього та пізнього строків становила $55,2 \mathrm{~cm}$ та 44,8 см відповідно, 12 липня - 69,1 см (ранній та пізній строки - 59,4 см та 62,5 см відповідно), 23 липня - 72,5 см (ранній та пізній строк $-65,8$ см і 65,2 см). Проте, у процесі підрахунків 23 липня зафіксовано, що за пізнього строку сівби не інокульованим насінням висота рослин була більшою, ніж за оптимального та раннього строку без інокуляції біопрепаратом (пізній строк $70,8 \mathrm{~cm})$.

Кращий розвиток листкового апарату на всіх ділянках спостерігався за раннього строку сівби як на варіантах оброблених «Ризогуміном», так i не інокульованих. Проте, порівнюючи їх, найбільш облистяними виявилися рослини на варіантах, оброблених біопрепаратом. Станом на 23 липня найкращий розвиток листкового апарату спостерігався за раннього та оптимального строків сівби інокульованим насінням, а кількість листків з однієї рослини в середньому становила 19,2 шт., тоді як за пізнього строку 18,7 штук. Найменш облистяними виявилися рослини на варіантах другого строку сівби, не інокульовані «Ризогуміном» (11 штук).

1. Фенологічні спостереження за розвитком рослин сої за різних строків сівби, 2012 р.

\begin{tabular}{|c|c|c|c|c|c|c|}
\hline Строки сівби & Сходи & Цвітіння & $\begin{array}{c}\text { Утворення } \\
\text { бобів у серед- } \\
\text { ньому ярусі }\end{array}$ & $\begin{array}{c}\text { Налив бобів } \\
\text { уередньому } \\
\text { ярусі }\end{array}$ & $\begin{array}{c}\text { Повна } \\
\text { стиглість }\end{array}$ & $\begin{array}{c}\text { Вегетаційний } \\
\text { період, днів }\end{array}$ \\
\hline Ранній & 05.05 & 14.06 & 26.06 & 13.07 & 13.08 & 100 \\
\hline Оптимальний & 14.05 & 18.06 & 5.07 & 20.07 & 16.08 & 94 \\
\hline Пізній & 23.05 & 29.06 & 13.07 & 23.07 & 20.08 & 91 \\
\hline
\end{tabular}




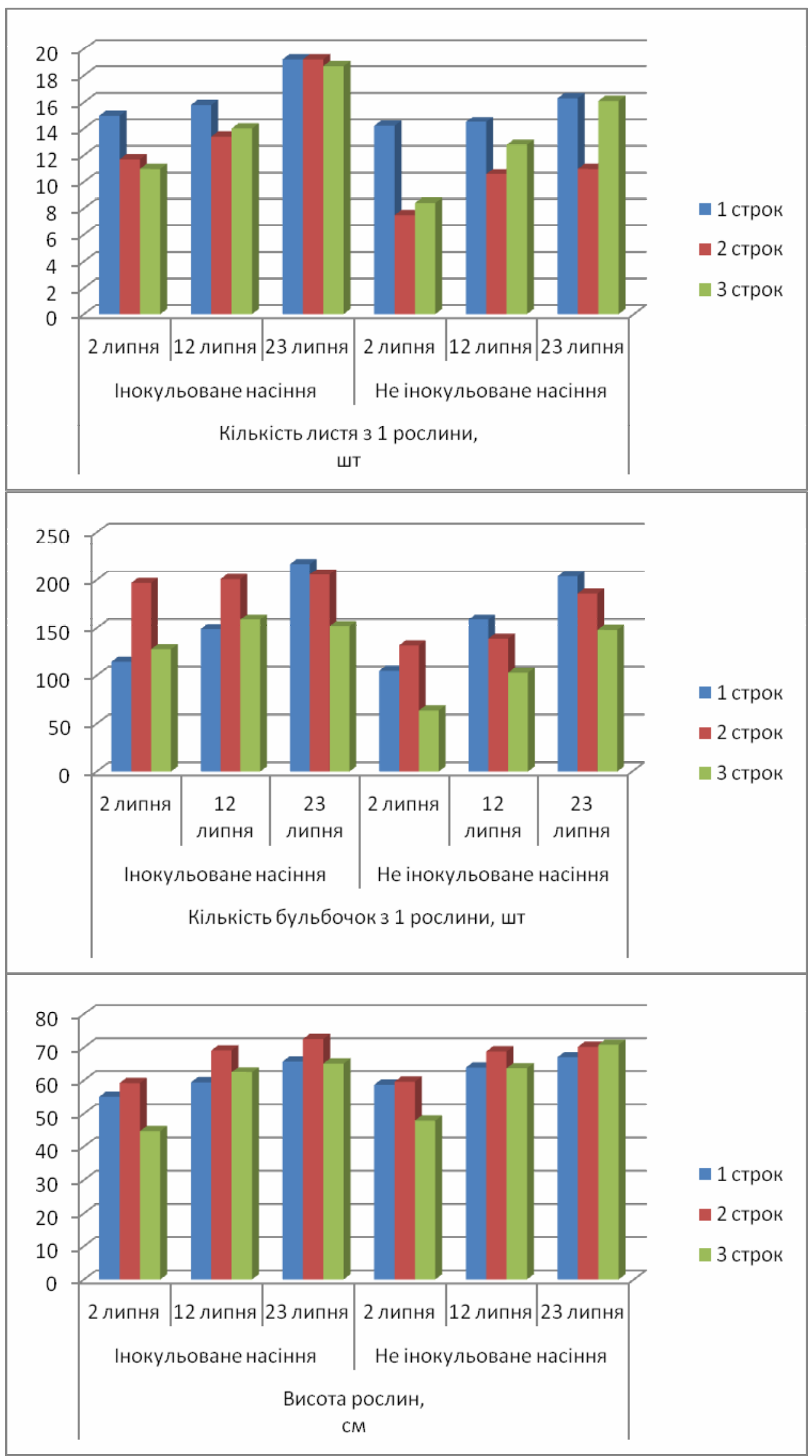

Рис. Динаміка росту і розвитку рослин залежно від елементів технологї̈, 2012 р. 
2. Маса 1000 насінин сої залежно від строків сівби насіння в 2012 p., 2

\begin{tabular}{|c|c|c|c|}
\hline & 1-й строк сівби & 2-й строк сівби & 3-й строк сівби \\
\hline Інокульоване насіння & 137,5 & 134,2 & 134,0 \\
\hline Необроблене насіння & 128,9 & 127,8 & 127,5 \\
\hline
\end{tabular}

3. Структурні показники сої залежсно від інокуляції насіння та строків сівби, 2012 р.

\begin{tabular}{|c|c|c|}
\hline Варіанти досліду & Кількість бобів на одній рослині, шт. & Кількість зерен на одній рослині, шт. \\
\hline \multicolumn{3}{|c|}{ Сівба інокульованим насінням } \\
\hline 1-й строк сівби & 39,8 & 64,7 \\
\hline 2-й строк сівби & 31,1 & 58,0 \\
\hline 3-й строк сівби & 25,2 & 41,8 \\
\hline \multicolumn{2}{|c|}{ Сівба неінокульованим насінням } \\
\hline 1-й строк сівби & 39,1 & 55,6 \\
\hline 2-й строк сівби & 23,5 & 44,6 \\
\hline 3-й строк сівби & 21,0 & 35,6 \\
\hline
\end{tabular}

Більша кількість та кращий розвиток бульбочок спостерігається на всіх трьох варіантах, інокульованих «Ризогуміном».

У цілому за всіх трьох строків рослини краще розвиваються на варіантах, інокульованих біопрепаратом, що відображається на якісних показниках врожаю, зокрема, масі 1000 насінин (табл. 2).

Як видно 3 даних таблиці, найбільшої маси досягло насіння, отримане 3 рослин першого строку сівби, оброблених «Ризогуміном» $(137,5$ г), а найменша маса спостерігається на варіанті, не обробленому біопрепаратом, висіяному в пізні строки (127,5 г). Найбільша кількість бобів та кількість насінин з однісї рослини за екстремальних погодних умов 2012 року також спостерігається за першого строку сівби інокульованим насінням (табл. 3 ), що становила

\section{БІБЛІОГРАФІЯ}

1. Ефективність симбіотичної азотфіксації в агроценозах України / С. В. Дідович, М. 3. Толкачов, О. Ю. Бутвіна // Сільськогосподарська мікробіологія: Міжвід. темат. наук. зб. - Чернігів, 2008. - Вип. 8. - С. 117-125.

2. http://www.agroscience.com.ua/plant/64-sivba-soi

3. http://agrocart.com/33/biologicheskij-azot-v-zemledelii 4. http://agroua.net/plant/catalog/cg-3/c-74/info/cag-225/ в середньому: кількість бобів - 39,8 шт., кількість зерен - 64,7 штук.

\section{Висновки:}

1. Урожайність сої та якість врожаю залежать як від строків сівби, так і від передпосівної обробки мікробіологічним препаратом. На ділянках, на яких рослини були оброблені «Ризогуміном» за сівби, структурні показники урожайності та маса 1000 насінин були вищими за всіх строків сівби. Спостерігалася також більша кількість і кращий розвиток бульбочок, що свідчить про інтенсивну азотфіксацію.

2. За різних строків сівби та різної забезпеченості продуктивною вологою на 6-9 днів відрізнялася тривалість вегетаційного періоду. Найдовшим він був за раннього строку сівби (100 днів) і в подальшому; за оптимальної та пізньої сівби він скоротився до 94 та 91 дня відповідно.

5. http://www.agrobox.com.ua/?PAGE=articles\&id= 164\&aid $=2$

6. http://stud24.ru/botany/azotfksujuch-bakter /469488-1782940-page1.html

7. http://archive.nbuv.gov.ua/portal/chem biol/ sgmb/2008_8/2008a/SM8_11.pdf

8. R. Casey, D. R. Davies. Peas: Genetics, Molecular Biology and Biotechnology. - UK, 1993. - C. 237. 